J. Clin. Chem. Clin. Biochem.

Vol. 27, 1989, pp. 967-972

(C) 1989 Walter de Gruyter \& Co.

Berlin - New York

\title{
Effect of Deproteinization and Reagent Buffer on the Enzymatic Assay of $L$-Carnitine in Serum
}

\author{
By F. P. W. Tegelaers, Margery M. G. Pickkers and P. J. Seelen \\ Department of Clinical Chemistry, Westeinde Hospital, The Hague, The Netherlands
}

(Received April 11/August 9, 1989)

Summary: Tris and HEPES were systematically compared as buffers for the enzymatic assay of $L$-carnitine. The deproteinization methods preceding the assay were also compared. The following conclusions were drawn.

1. Both Tris and HEPES act on the catalytic site of the enzyme, acetylCoA : carnitine O-acetyltransferase (EC 2.3.1.7), which is used for the conversion of $L$-carnitine to acetylcarnitine. HEPES is a competitive inhibitor, and no acetylated product of HEPES is formed. In the presence of Tris a limited amount of acetylTris is formed, and an appropriate blank corrects for this effect.

2. The incubation time of the assay is strongly influenced by the preceding deproteinization method. The enzyme is influenced by inorganic salt, which acts as a competitive inhibitor.

3. If Tris is used in place of HEPES in end-point assays, optimal conditions and shorter assay times are achieved with less enzyme and less acetylCoA, provided more elaborate deproteinization methods are used.

4. The HEPES system is more costly, but preferable for the determination of both total and free $L$-carnitine in combination with a matched deproteinization method.

\section{Introduction}

$L$-Carnitine functions primarily in the transport of fatty acids across the mitochondrial membrane (1). It is present either free or esterified (1). Subnormal concentrations in serum may result from a primary cause (2), or can be secondary to pathological conditions such as kidney disease and dialysis $(3,4)$, parenteral nutrition (5) or inborn errors of metabolism (6). These conditions affect the metabolic processing of fatty acids. $L$-Carnitine is easily esterified in vitro, and this

1) Enzyme

AcetylCoA : carnitine O-acetyltransferase (EC 2.3.1.7)

2) Abbreviations

CoASH coenżyme A

EDTA ethylenediaminetetra-acetic acid

HEPES N-2-hydroxyethylpiperazine- $\mathrm{N}^{\prime}$-ethanesulphonic acid

MOPS 3-(N-morpholino)propanesulphonic acid

Tris Tris(hydroxymethyl)aminomethane process can be exploited for measuring both free and total serum $L$-carnitine. Several methods have been described for the measurement of $L$-carnitine in serum or plasma. Marquis \& Fritz developed an enzymatic assay (7): acetylCoA : carnitine O-acetyltransferase $(\text { EC 2.3.1.7 })^{1}$ ) catalyses the formation of acetylcarnitine and $\mathrm{CoASH}^{2}$ ) from $L$-carnitine and acetylCoA. $\mathrm{CoASH}^{2}$ ) reacts with 5,5'-dithiobis-(2-nitrobenzoic acid) to form 5-thio-2-nitrobenzoate, which can be measured at $412 \mathrm{~nm}$. Deproteinization is necessary to avoid non-specific reduction of 5,5'-dithiobis-(2-nitrobenzoic acid). The procedure has been variously modified with respect to deproteinization, hydrolysis of esterified $L$-carnitine, and the nature of the buffer $(8-10)$.

We compared different assay conditions, and we studied the influence of deproteinization, hydrolysis, and buffer on the performance of the assay. 


\section{Materials and Methods}

Materials

AcetylCoA : carnitine O-acetyltransferase (EC 2.3.1.7), $D L$-acetylcarnitine and acetylCoA were purchased from Boehringer, Mannheim (FRG); L-carnitine and 5,5'-dithiobis-(2-nitrobenzoic acid) were from Sigma, St. Louis, MO 63178 (USA); other chemicals of analytical grade were obtained from Merck, Darmstadt (FRG).

\section{Methods}

For deproteinization of serum without subsequent hydrolysis of $L$-carnitine esters the following methods were used:

1: the perchloric acid method

Serum $(2.0 \mathrm{ml})$ was mixed with $0.5 \mathrm{ml}(140 \mathrm{~g} / \mathrm{l})$ of cold $\mathrm{HClO}_{4}$. After $30 \mathrm{~min}$ at $4{ }^{\circ} \mathrm{C}$ the mixture was centrifuged for $5 \mathrm{~min}$ at $10000 \mathrm{~g}$. To $1.0 \mathrm{ml}$ of supernatant cold $0.5 \mathrm{~mol} / 1 \mathrm{MOPS}^{2}$ ) in $2.0 \mathrm{~mol} / 1 \mathrm{KOH}$ or solid $\mathrm{KHCO}_{3}$ was added until the $\mathrm{pH}$ was between 7 and 8 . After $30 \mathrm{~min}$ at $4{ }^{\circ} \mathrm{C}$ the mixture was centrifuged for $5 \mathrm{~min}$ at $10000 \mathrm{~g}$. The clear supernatant was used for the assay.

\section{2: the trichloroacetic acid method}

Serum $(2.0 \mathrm{ml})$ was mixed with $0.5 \mathrm{ml}(200 \mathrm{~g} / \mathrm{l})$ of cold trichloroacetic acid. After $30 \mathrm{~min}$ at $4^{\circ} \mathrm{C}$ the mixture was centrifuged for $5 \mathrm{~min}$ at $10000 \mathrm{~g}$. To the supernatant $2.0 \mathrm{~mol} / \mathrm{l} \mathrm{NaOH}$ was added until the $\mathrm{pH}$ was between 7 and 8 , or the supernatant was extracted with $7.5 \mathrm{ml}$ of diethyl ether to remove trichloroacetic acid. This was repeated twice until the $\mathrm{pH}$ was between 6 and 7. Remaining traces of diethyl ether were removed by a gentle nitrogen stream.

3: the $\mathrm{ZnSO}_{4}-\mathrm{Ba}(\mathrm{OH})_{2}$ method

This method was performed according to Seccombe et al. (8).

4: the heat denaturation and freeze-thawing method

This method was performed according to Rodriguez-Segade et al. (9).

In all methods a Cryofuge 5000 (Heraeus Christ, Osterode/ Harz, FRG) was used for centrifugation.

\section{Deproteinization with subsequent hydrolysis of L-carnitine esters}

Serum $(2.0 \mathrm{ml})$ was mixed with $0.5 \mathrm{ml}(140 \mathrm{~g} / \mathrm{l})$ of cold $\mathrm{HClO}_{4}$. After $30 \mathrm{~min}$ at $4{ }^{\circ} \mathrm{C}$ and subsequent centrifugation for $5 \mathrm{~min}$ at $10000 \mathrm{~g}, 0.2 \mathrm{ml}$ of $\mathrm{KOH}(5 \mathrm{~mol} / \mathrm{l})$ was added to $1.5 \mathrm{ml}$ of the supernatant. After $10 \mathrm{~min}$ at $4^{\circ} \mathrm{C}$, the sample was centrifuged for $5 \mathrm{~min}$ at $10000 \mathrm{~g}$ and the supernatant was incubated at $80^{\circ} \mathrm{C}$ for $60 \mathrm{~min}$. Cold $\mathrm{HClO}_{4}$ was added until the $\mathrm{pH}$ was $<7$. After centrifugation for $10 \mathrm{~min}$ at $10000 \mathrm{~g}$, solid $\mathrm{KHCO}_{3}$ was added to the supernatant until the $\mathrm{pH}$ was between 7 and 8. After centrifugation, the clear supernatant was used for the assay.

\section{Assays}

For the enzymatic assay of $L$-carnitine two methods were compared. The first method was according to the procedure as described by Wieland et al. (11). To $1.0 \mathrm{ml}$ of deproteinized serum or standard solution, $0.9 \mathrm{ml}$ reagent was added. The reaction was started with $0.1 \mathrm{ml}$ of acetylCoA : carnitine Oacetyltransferase $(0.25 \mathrm{~g} / \mathrm{l}, 80 \mathrm{kU} / \mathrm{g})$. Final reagent concentrations are summarized in table 1.

The second method was as described by Pearson et al. (12). To $1.0 \mathrm{ml}$ of deproteinized serum or standard solution, $1.0 \mathrm{ml}$ of reagent was added. The reaction was started by the addition of $10 \mu \mathrm{l}$ of acetylCoA : carnitine O-acetyltransferase $(1 \mathrm{~g} / 1,80$ $\mathrm{kU} / \mathrm{g}$ ). Final reagent concentrations are summarized in table 1 .
Tab. 1. Final reagent concentrations in commonly used enzymatic $L$-carnitine assays.

\begin{tabular}{|c|c|c|c|}
\hline \multirow{2}{*}{$\begin{array}{l}\text { Reagent } \\
\text { HEPES KOH pH } 7.5\end{array}$} & $\begin{array}{l}\text { Tris-buffered } \\
\text { assay } \\
\text { (Pearson et al.) }\end{array}$ & \multicolumn{2}{|c|}{$\begin{array}{l}\text { HEPES-buffered } \\
\text { assay } \\
\text { (Wieland et al.) }\end{array}$} \\
\hline & - & 36 & $\mathrm{mmol} / \mathrm{l}$ \\
\hline Tris-HCl pH 7.8 & $100 \mathrm{mmol} / \mathrm{l}$ & - & \\
\hline $\begin{array}{l}\text { 5,5'-Dithiobis-(2- } \\
\text { nitrobenzoic acid }\end{array}$ & $0.125 \mathrm{mmol} / \mathrm{i}^{\prime}$ & 0.200 & $\mathrm{mmol} / \mathrm{l}$ \\
\hline EDTA & $1.25 \mathrm{mmol} / 1$ & 0.72 & mimol/1 \\
\hline AcetylCoA & $0.20 \mathrm{mmol} / 1$ & 0.55 & $\mathrm{mmol} / \mathrm{l}$ \\
\hline $\begin{array}{c}\text { AcetylCoA : carnitine- } \\
\text { O-acetyltransferase }\end{array}$ & $0.8 \mathrm{U}$ & 2 & $\mathbf{U}$ \\
\hline
\end{tabular}

Standards were made by dilution of a $L$-carnitine stock solution ( $1 \mathrm{mmol} / \mathrm{l}$ ) with isotonic saline. To investigate the effect of salt, the stock solution was diluted with solutions of $\mathrm{NaCl}, \mathrm{K}_{2} \mathrm{SO}_{4}$ or sucrose to the desired concentration and conductivity c. q. osmolality. For the reagent blank, iso-osmotic saline solutions were used.

Absorbances $\left(\mathrm{A}_{412 \mathrm{~nm}}\right)$ of the reaction mixtures were measured continuously at $25^{\circ} \mathrm{C}$ for 5 to $15 \mathrm{~min}$ on a Perkin Elmer 554 spectrophotometer (Perkin Elmer Corp., Norwalk CT 06856, USA). The molar lineic absorbance of 5-thio-2-nitrobenzoate is $1360 \mathrm{~m}^{2} / \mathrm{mol}(13)$. Osmolalities were measured on a Vapor Pressure Osmometer (Wescor Inc., Logan, Utah 84321, USA). Conductivities were measured on a Radiometer DCM 83 Conductivity Meter (Radiometer, Copenhagen, Denmark).

\section{Results}

The time required for complete conversion of $L$-carnitine to acetylcarnitine is dependent upon the conditions of the assay. In figure 1 , lines $a, b, g$ and $h$ show the effect of deproteinization methods on the reaction times in the assay system according to Pearson et al. Similar results were obtained with the HEPES-buffered assay according to Wieland et al. (lines $c, d, f$ ). The shortest reaction times were obtained with a Tris ${ }^{2}$ )-buffered assay.

\section{The effect of the reagent buffer}

The ability of acetylCoA:carnitine O-acetyltransferase $^{1}$ ) to acetylate Tris is shown in figure 2. Assay conditions were according to Pearson et al., but $L$ carnitine was omitted and the concentration of Tris in the assay was varied. $\mathrm{NaCl}$ was added to obtain the same conductivity in all assays. Tris is acetylated by the enzyme, the $K_{\mathrm{m}}$ of the reaction being 175 $\mathrm{mmol} / 1$ and the $V_{\max } 1.3 \mathrm{nmol} / \mathrm{min}$. No acetylation of HEPES $^{2}$ ) was found. Nevertheless, figure 3 shows a competitive inhibitory effect of HEPES on the acetylation of $L$-carnitine in the Tris-buffered system according to Pearson et al. HEPES influences the acetylation of Tris in a similar way (not shown).

Similar effects are obtained when another Good's buffer, MOPS ${ }^{2}$ ), is used. 


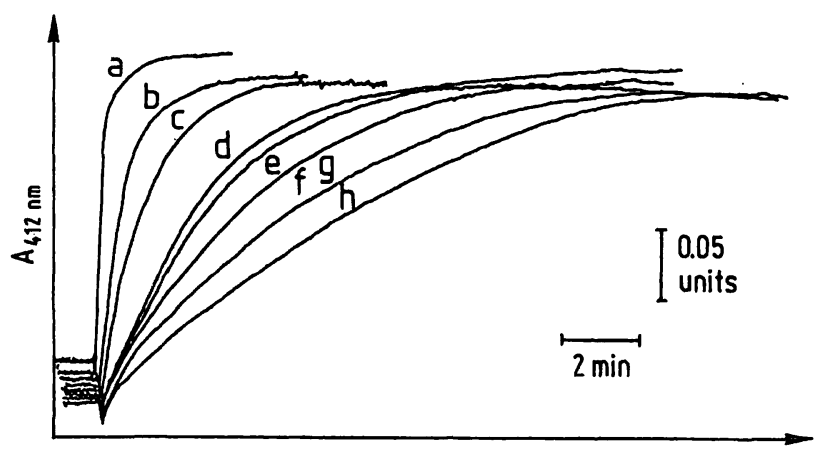

Reaction time of assay

Fig. 1. Reaction times of $L$-carnitine assays. Different assay conditions (buffer type, enzyme and acetylCoA concentration) and different deproteinization methods were used.

line a: Tris-buffered assay according to Pearson et al. (12); aqueous $L$-carnitine standard (no deproteinization).

line b: Tris-buffered assay according to Pearson et al. (12); trichloroacetic acid deproteinization with ether extraction neutralization.

line c: HEPES-buffered assay according to Wieland et al. (11); $\mathrm{HClO}_{4}$ deproteinization with $\mathrm{KHCO}_{3}$ neutralization.

line d: HEPES-buffered assay according to Wieland et al. (11); trichloroacetic acid deproteinization with ether extraction neutralization.

line e: Tris-buffered assay according to Pearson et al. (12), but enzyme and acetylCoA concentration as in the HEPES-buffered assay according to Wieland et al. (11); $\mathrm{HClO}_{4}$ deproteinization with $\mathrm{KHCO}_{3}$ neutralization. line $\mathrm{f}$ : HEPES-buffered assay according to Wieland et al. (11); aqueous $L$-carnitine standard (no deproteinization).

line g: Tris-buffered assay according to Pearson et al. (12); $\mathrm{HClO}_{4}$ deproteinization with $\mathrm{KHCO}_{3}$ neutralization.

line h: Tris-buffered assay according to Pearson et al. (12); $\mathrm{HClO}_{4}$ deproteinization with MOPS-KOH neutralization.

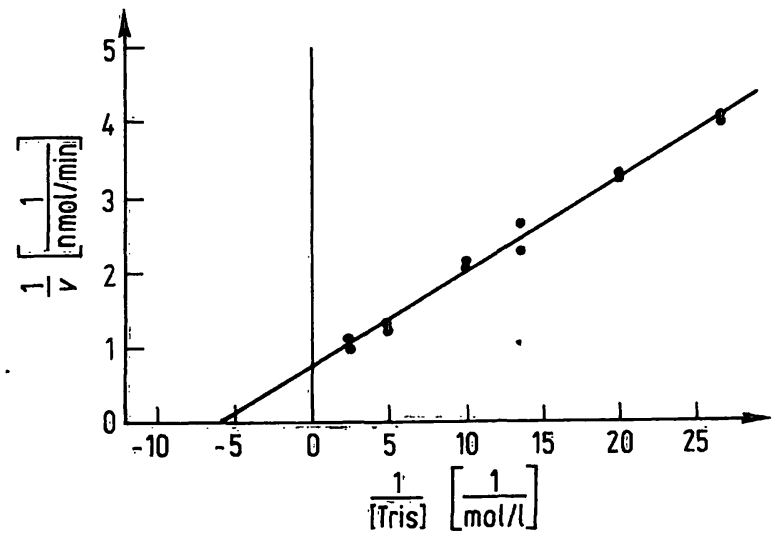

Fig. 2. Lineweaver-Burk plot of acetylCoA : carnitine O-acetyltransferase.

The concentration of Tris was varied; the osmolality of the assay was kept constant at $254 \mathrm{mosmol} / \mathrm{kg}$ with $\mathrm{NaCl}$. Further conditions were as described in Materials and Methods.

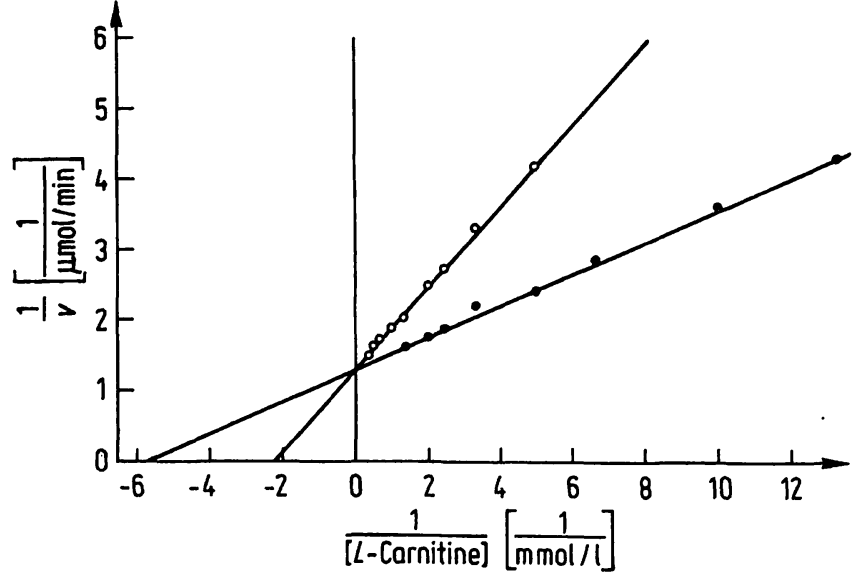

Fig. 3. The effect of HEPES on the kinetics of acetylCoA : carnitine O-acetyltransferase.

HEPES was added to the Tris-buffered assay with variable $L$-carnitine concentrations: $0-0$ : no addition; $0-0$ : addition $100 \mathrm{mmol} / \mathrm{l}$. Conditions were as described in Materials and Methods.

\section{The effect of deproteinization}

The effect of salt on the kinetics of acetylCoA: carnitine $\mathrm{O}$-acetyltransferase is shown in figure 4.

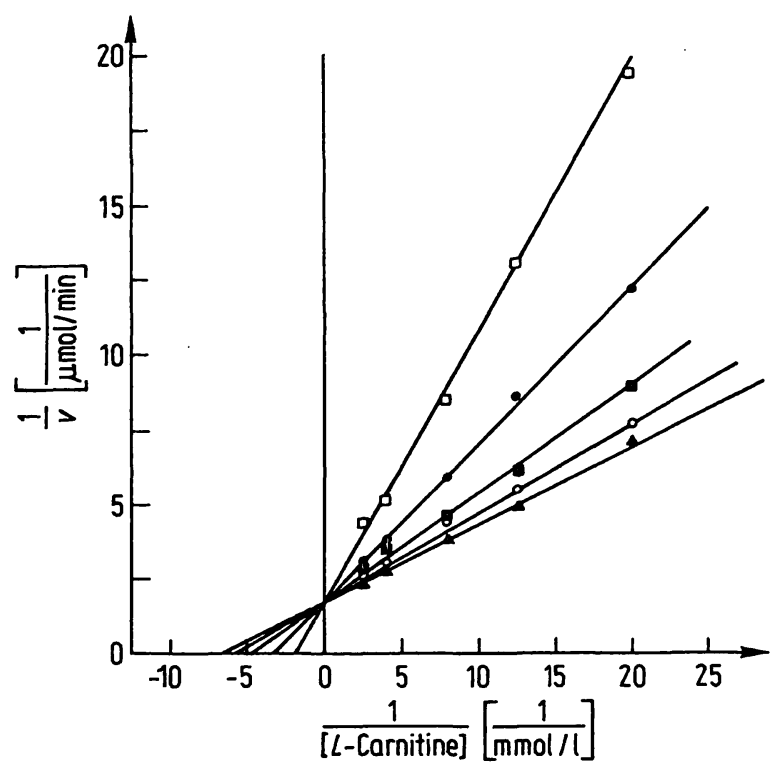

Fig. 4. The effect of sodium chloride on the kinetics of acetylCoA : carnitine $\mathrm{O}$-acetyltransferase.

Different concentrations of $\mathrm{NaCl}$ were added to the Tris-buffered assay. Conditions were as described in Materials and Methods, exept for O- 0 : here, $50 \mathrm{mmol} / \mathrm{l}$ Tris was present in the assay instead of $100 \mathrm{mmol} / \mathrm{l}$. After complete conversion of $L$-carnitine to acetylcarnitine, osmolalities and conductivities were measured.

\begin{tabular}{llll}
\hline Line & $\begin{array}{l}\mathrm{NaCl} \text { in } \\
\text { assay } \\
\text { mmol/1 }\end{array}$ & $\begin{array}{l}\text { Osmolality } \\
\text { mosmol/kg }\end{array}$ & $\begin{array}{l}\text { Conductivity } \\
\mathrm{mS} / \mathrm{cm}\end{array}$ \\
\hline $0-0$ & - & 159 & 3.9 \\
$\Delta-\Delta$ & - & 198 & 6.9 \\
$\square-0$ & 100 & 295 & 11.0 \\
$0-0$ & 200 & 373 & 17.4 \\
$\square-\square$ & 300 & 513 & 23.7
\end{tabular}




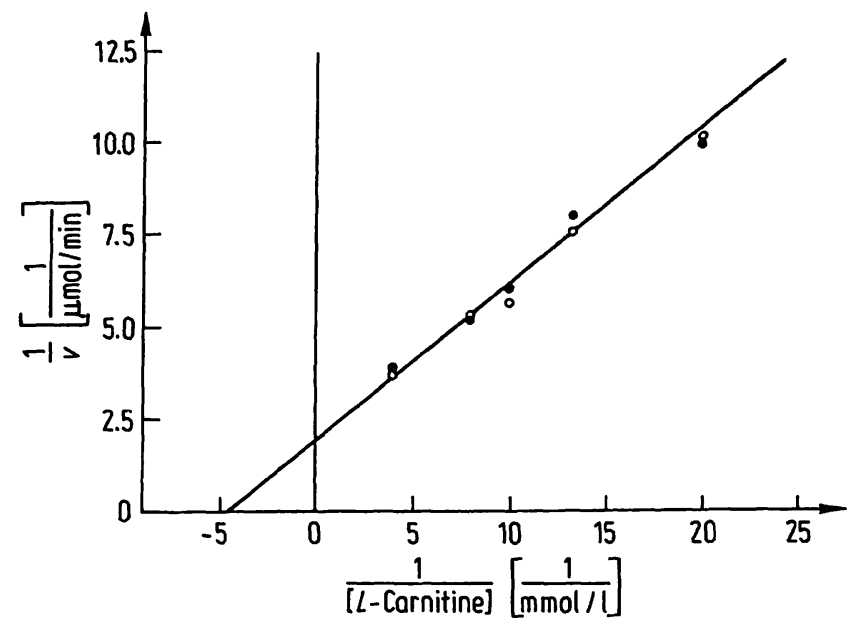

Fig. 5. The effect of potassium sulphate and sodium chloride on the kinetics of acetylCoA:carnitine O-acetyltransferase.

The Tris-buffered assay was used. Conditions were as described in Materials and Methods.

○-० $\mathrm{K}_{2} \mathrm{SO}_{4} 140 \mathrm{mmol} / \mathrm{l} ; \bullet-\bullet \mathrm{NaCl} 200 \mathrm{mmol} / \mathrm{l}$. After complete conversion of $L$-carnitine to acetylcarnitine, osmolalities and conductivities were: $(0-0) 355$ mosmol $/ \mathrm{kg}$ and $16.4 \mathrm{mS} / \mathrm{cm}$; (-0) $360 \mathrm{mosmol} / \mathrm{kg}$ and $15.8 \mathrm{mS} / \mathrm{cm}$.

Using aqueous $L$-carnitine standards, LineweaverBurk plots were made at different $\mathrm{NaCl}$ concentrations. The lowest $K_{m}$ is seen under the conditions described by Pearson et al. Increasing the concentration of $\mathrm{NaCl}$ to $300 \mathrm{mmol} / 1$ results in an increase of the $K_{\mathrm{m}}$ to $435 \mu \mathrm{mol} / \mathrm{l}$. No effect on the $V_{\max }$ was observed. To exclude an effect of $\mathrm{NaCl}$ itself on the enzyme, $\mathrm{K}_{2} \mathrm{SO}_{4}(140 \mathrm{mmol} / \mathrm{l})$ was added instead of $\mathrm{NaCl}(200 \mathrm{mmol} / \mathrm{l})$. At identical osmolalities and conductivities no significant differences were observed (fig. 5) suggesting that the enzyme was influenced by the ionic strength in the assay. This was confirmed by the observation (not shown) that no increase in $K_{\mathrm{m}}$ was observed when sucrose was added to the assay, i.e. when the osmolality but not the ionic strength was increased.

Similar results were obtained with the HEPES-buffered assay according to Wieland et al. (not shown).

Deproteinization methods affect the conductivities and osmolalities of the Tris-buffered assays according to Pearson et al. (tab. 2). This is reflected in the time for the complete enzymatic conversion of $L$-carnitine to acetylcarnitine (fig. 1, line a, b, g, h). Similar effects are obtained with the HEPES-buffered assay according to Wieland et al., in which the osmolality is 106 mosmol $/ \mathrm{kg}$ after the addition of an aqueous $L$-carnitine standard (fig. 1, line $\mathrm{f}$ ). After the addition of a serum that had been deproteinized with $\mathrm{HClO}_{4}$ and neutralized with $\mathrm{KHCO}_{3}$, the osmolality was 331 mos$\mathrm{mol} / \mathrm{kg}$ (fig. 1, line c).
Tab. 2. Osmolality and conductivity in the assay mixtures after deproteinization according to different methods.

\begin{tabular}{|c|c|c|}
\hline Method & $\begin{array}{l}\text { Osmolality } \\
\text { mosmol/kg }\end{array}$ & $\begin{array}{l}\text { Conductivity } \\
\mathrm{mS} / \mathrm{cm}\end{array}$ \\
\hline $\begin{array}{l}\text { 1: Trichloroacetic acid; } \\
\text { ether extraction }\end{array}$ & 330 & 11.4 \\
\hline $\begin{array}{l}\text { 2: Trichloroacetic acid; } \\
\mathrm{NaOH} \text { neutralization }\end{array}$ & , i & 14.6 \\
\hline $\begin{array}{l}\text { 3: } \mathrm{HClO}_{4} \text {; MOPS-KOH neu- } \\
\text { tralization }\end{array}$ & 375 & 13.7 \\
\hline $\begin{array}{l}\text { 4: } \mathrm{HClO}_{4} ; \mathrm{KHCO}_{3} \text { neu- } \\
\text { tralization }\end{array}$ & 415 & 14.1 \\
\hline 5: $\mathrm{ZnSO}_{4}-\mathrm{Ba}(\mathrm{OH})_{2}$ & 210 & 7.4 \\
\hline 6: Heat-Freeze-Thaw & 300 & 11.0 \\
\hline 7: Non-deproteinized serum & 300 & 11.1 \\
\hline 8: Water & 200 & 7.0 \\
\hline
\end{tabular}

1-6: serum was deproteinized as described in Materials and Methods, and $1 \mathrm{ml}$ of supernatant was added to $1 \mathrm{ml}$ of assay mixture. Final concentrations were as described in Materials and Methods, according to the method of Pearson et al. After complete conversion of $L$-carnitine to acetylcarnitine, osmolalities and conductivities were measured.

7-8: as a control, $1 \mathrm{ml}$ of non-deproteinized serum (7) or $1 \mathrm{ml}$ of water (8) was added to the assay reagent instead of deproteinized serum.

The combination of reagent buffer and deproteinization

A comparison of results obtained with the HEPESbuffered assay of Wieland et al. and with the Trisbuffered assay of Pearson et al. is shown in table 3. Omission of a reagent blank in the latter assay results in a minor increase of the measured value. In table 3 the trichloroacetic acid method with subsequent ether extraction is used for deproteinization. In table $3 \mathrm{~b}$ the

Tab. 3. Intra-assay variation of $L$-carnitine in two pool sera, as measured with enzymatic assays containing HEPES or Tris buffer.

\begin{tabular}{|c|c|c|c|c|}
\hline & $\begin{array}{l}\text { Pool se } \\
\text { mean } \\
\mu \text { mol/l }\end{array}$ & $\begin{array}{l}\text { rum } 1 \\
\mathrm{CV} \\
\%\end{array}$ & $\begin{array}{l}\text { Pool se } \\
\text { mean } \\
\mu \text { mol/1 }\end{array}$ & $\begin{array}{l}\text { CV } 2 \\
\% \\
\%\end{array}$ \\
\hline \multicolumn{5}{|c|}{ a: Trichloroacetic acid; ether extraction } \\
\hline & 35.8 & 5.1 & 52.1 & 4.7 \\
\hline & 35.0 & 3.1 & 51.5 & 2.1 \\
\hline & 36.2 & 3.0 & 52.7 & 2.2 \\
\hline \multirow{4}{*}{$\begin{array}{l}\text { b: } \mathrm{HClO}_{4} ; \mathrm{KHCO}_{3} \\
\text { 1: } \mathrm{HEPES}-\text { buffered assay: } \\
\text { 2: Tris-buffered assay, } \\
\text { including blank: } \\
\text { without blank: }\end{array}$} & & & & \\
\hline & 35.1 & 3.9 & 51.9 & 2.8 \\
\hline & 36.1 & 10.2 & 53.0 & 7.6 \\
\hline & 38.0 & 9.9 & 54.1 & 8.1 \\
\hline
\end{tabular}

Assays were as described in Materials and Methods $(n=15)$. Sera were deproteinized, either by the trichloroacetic acid method with subsequent neutralization by ether extraction (a), or by the perchloric acid method with subsequent $\mathrm{KHCO}_{3}$ neutralization (b). For the reagent blank, $\mathrm{NaCl}$ was added insteand of serum to obtain the same assay osmolality. 
perchloric acid method with subsequent $\mathrm{KHCO}_{3}$ neutralization is used. By using this method of deproteinization, carnitine esters are hydrolysed and the recoveries of added $L$-carnitine and acetylcarnitine are between $89 \%$ and $103 \%$. Moreover, dilution is minimal and no extra salt is introduced, compared with the non-hydrolysed sample (osmolalities: 428 $\pm 38 \mathrm{mosmol} / \mathrm{l}$ vs. $431 \pm 32 \mathrm{mosmol} / \mathrm{l} ; \mathrm{n}=5$ ).

\section{Discussion}

Several enzymatic methods, both manual and automated, for the determination of $L$-carnitine in serum or plasma have been described $(7-10,14,15)$. Most of them are colorimetric assays. Their principal differences are in the buffer and in the deproteinization method that precedes the assay.

\section{The effect of reagent buffer}

Christiansen \& Bremer claim that Tris functions as an acetyl-group receptor (16). HEPES is not acetylated and is therefore recommended (16). These results are often referred to by other HEPES-using authors, and they are even used to explain grossly differing results (17).

We studied the acetylation of Tris in the assay system of Pearson et al. and quantitated the amount of acetylated product by the formation of 5-thio-2-nitrobenzoate. When the concentration of Tris in the assay was $100 \mathrm{mmol} / \mathrm{l}$, about $2 \mu \mathrm{mol} / 1$ of acetylTris was formed in a reaction time of $5 \mathrm{~min}$, whereas reference values of free $L$-carnitine range from 30 to $70 \mu \mathrm{mol} / 1$. Longer incubation times lead to an increase in the formation of acetylTris, but a reagent blank corrects for this effect (tab. 3). Although the amount of acetylTris that is formed depends upon the assay, the formation of this compound should not be held responsible for the wide variation of results, as proposed by Fürst \& Glöggler (17).

It is stated that HEPES is not acetylated and that it therefore does not interfere with the assay (16). This is only partially true. We have shown that HEPES functions as a competitive inhibitor of the enzyme. The same effect is observed with another Good's buffer, MOPS. The catalytic centre of the enzyme must have affinity for these buffers, despite the fact that there is no detectable formation of an acetylated product. This could explain why higher concentrations of acetylCoA : carnitine O-acetyltransferase and acetylCoA are needed in the HEPES-buffered system according to Wieland et al. to obtain acceptable reaction times.

\section{The effect of deproteinization}

The efficiency of the assay is not only dependent upon the choice of the buffer. It should also be recognized that the efficiency is influenced by the deproteinization method preceding the assay. It is clear that these methods introduce a variable amount of salt (tab. 2). Even serum electrolytes affect the ionic strength. The $\mathrm{ZnSO}_{4}-\mathrm{Ba}(\mathrm{OH})_{2}$ method (8) seems more appropriate for keeping the ionic strength low, but this is due to dilution, thus decreasing the sensitivity of the assay. Amicon filter cones $(8,10)$, or the heat denaturation of freeze-thawing method (9) and the trichloroacetic acid method with subsequent ether extraction (18) have the least effect, but they are either expensive (Amicon) or elaborate.

The negative effect of salt on the properties of acetylCoA:carnitine $\mathrm{O}$-acetyltransferase is clearly demonstrated in figure 4 . The effect is independent of the nature of the salt (fig. 5) and solely due to the ionic strength of the assay. Addition of sucrose has no effect at all. Salts act as if they were competitive inhibitors. This could be due to masking of charges on molecules (Debye-Hückel effect). Increased amounts of acetylCoA : carnitine O-acetyltransferase and acetylCoA are required in the assay to obtain acceptable reaction times (fig. 1, line e, g). Thus the choice of the buffer should be combined with the choice of the deproteinization method.

The combination of buffer and deproteinization

One can use the Tris-buffered assay according to Pearson et al. A reagent blank is necessary, as well as a deproteinization method that introduced a minimum amount of salt, e.g. heat denaturation and freeze thawing or trichloroacetic acid with subsequent ether extraction. With the latter method, the overall performance is similar to the HEPES-buffered assay (tab. 3). If a deproteinization method is used that introduces more salt, then more acetylCoA and more acetylCoA : carnitine $\mathrm{O}$-acetyltransferase are required in the assay for acceptable results, thereby depriving the Tris-buffered method of its only advantage (fig. 1 , line $e, f$. A disadvantage of ether extraction is that long chain acylcarnitines may also be extracted, so that the method is not suitable for the determination of total $L$-carnitine.

The second possibility is the use of the HEPES-buffered assay according to Wieland et al. in combination with perchloric acid deproteinization with subsequent $\mathrm{KHCO}_{3}$ neutralization (fig. 1, line c). Due to the unfavourably low osmolality of the HEPES-buffered 
assay $( \pm 100 \mathrm{mosmol} / \mathrm{kg})$, the reaction with an aqueous $L$-carnitine standard is very slow (fig. 1 , line $\mathrm{f}$. The addition of salt increases the osmolality of the assay towards optimal values and decreases the reaction time (fig. 1 , line $c, d$ ). This is in contrast to the Tris-buffered assay. With an aqueous $L$-carnitine standard the osmolality is already in the optimal range, so that additional salt increases the osmolality away from optimal values, and the reaction time increases (fig. 1, line a, b, g). Also, concentrations of acetylCoA and acetylCoA : carnitine O-acetyltransferase are higher in the HEPES-buffered assay. The results from table 3 show that the preferred method is the HEPES-buffered assay in combination with the perchloric acid deproteinization with subsequent $\mathrm{KHCO}_{3}$ neutralization. An advantage of this method is the possibility of determining both free and acylated
$L$-carnitine. By using the proposed method for the hydrolysis of esterified carnitine esters, the amount of extra salt can be kept within the same limits as those in the unhydrolysed sample.

Thus we prefer methods that employ HEPES rather than Tris, because the deproteinization method is more convenient, and because it is possible to determine both total and free $L$-carnitine. Moreover, the additional problem of the acetylation of Tris is avoided.

\section{Acknowledgement}

The authors wish to thank Dr W. Huisman, Dr M. C. Kroon and Dr E. T. Backer for stimulating discussions and comments and Mrs A. Panhuyzen for technical assistance.

\title{
References
}

1. Siliprandi, N., Sartorelli, L., Ciman, M. \& DiLisa, F. (1989) Carnitine: metabolism and clinical chemistry. Clin. Chim. Acta $183,3-12$

2. Chapoy, P. R., Angelini, C., Brown, J., Stiff, J. E., Shug, A. L. \& Cederbaum, S. D. (1980) Systemic carnitine deficiency A treatable inherited lipid-storage disease presenting as Reye's syndrome. N. Eng. J. Med. 24, 1389-1394.

3. Vacha, G. M., Giorcelli, G., Siliprandi, N. \& Corsi, M. (1983) Favorable effects of L-carnitine treatment on hypertriglyceridemia in hemodialysis patients: decisive role of low levels of high density lipoprotein-cholesterol. Am. J. Clin. Nutr. 38, 532-540.

4. Leschke, M., Rumpf, K. W., Eisenhauer, Th., Becker, K., Bock, U. \& Scheler, F. (1984) Serumspiegel und Urinausscheidung von L-Carnitin bei Patienten mit normaler und eingeschränkter Nierenfunktion. Klin. Wochenschr. 62, 274-277.

5. Worthley, L. I. G., Fishlock, R. C. \& Snoswell, A. M. (1983) Carnitine deficiency with hyperbilirubinemia, generalized skeletal muscle weakness and reactive hypoglycemia in a patient on long-term total parenteral nutrition: treatment with intravenous L-carnitine. J. Parent. Enter. Nutr. 7, 176-180.

6. DiDonato, S., Rimoldi, M., Garavaglia, B. \& Uziel, G. (1984) Propionylcarnitine excretion in propionic and methylmalonic acidurias: a cause of carnitine deficiency. Clin. Chim. Acta 139, 13-21.

7. Marquis, N. R. \& Fritz, I. B. (1964) Enzymological determination of free carnitine concentrations in rat tissues. $\mathrm{J}$. Lip. Res. 5, 184-187.

8. Seccombe, D. W., Dodek, P., Frohlich, J., Hahn, P., Skala, J. P. \& Campbell, D. J. (1976) Automated method for Lcarnitine determination. Clin. Chem. 22, 1589-1592.

9. Rodriguez-Segade, S., Dela Pena, C. A., Paz, J. M. \& Del Rio, R. (1985) Determination of L-carnitine in serum, and implementation on the ABA-100 and Centrifichem 600 . Clin. Chem. 31, 754-757.

10. Cederblad, G., Harper, P. \& Lindgren, K. (1986) Spectrophotometry of carnitine in biological fluids and tissue with a Cobas Bio centrifugal analyzer. Clin. Chem. 32, 342346.

11. Wieland, O. H., Deufel, T. \& Paetzke-Brunner, I. (1985) Free and esterified carnitines: Colorimetric method. In: Methods of Enzymatic Analysis. Third edit. (Bergmeyer, $\mathrm{H}$. U., ed.) Vol. VIII, pp. $481-488$, VCH Verlags-Gesellschaft.

12. Pearson, D. J., Tubbs, P. K. \& Chase, J. F. A. (1974) Carnitine and acylcarnitines. In: Methods of Enzymatic Analysis. Second edit. (Bergmeyer, H. U., ed.) pp. 17581771, Weinheim Verlag Chemie.

13. Ellman, G. L. (1960) Tissue sulfhydryl groups. Arch. Biochem. Biophys. 82, 70-77.

14. Deufel, T. \& Wieland, O. H. (1983) Sensitive assay of carnitine palmitoyl transferase in tissue homogenates with a modified spectrophotometric method for enzymatic carnitine determination. Clin. Chim. Acta 135, 247-251.

15. Rössle, C., Kohse, K. P., Franz, H. E. \& Fürst, P. (1985) An improved method for the determination of free and esterified carnitine. Clin. Chim. Acta 149, 263-268.

16. Christiansen, R. Z. \& Bremer, J. (1978) Acetylation of Tris(hydroxymethyl)aminomethane (Tris) and Tris derivatives by carnitine acetyltransferase. FEBS Letters 86, 99-102.

17. Fürst, P. \& Glöggler, A. (1987) Reappraisal of carnitine concentrations in blood. Clin. Chem. 33, 1956-1957.

18. Chauhan, M. S. \& Dakshinamurti, K. (1981) Flùorimetric assay of $\mathrm{B}_{6}$ vitamers in biological material. Clin. Chim. Acta 109, 159-167.

\author{
F. P. W. Tegelaers \\ Medical Centre Alkmaar \\ Dept. of Clinical Chemistry \\ Postbus 501 \\ NL-1800 AM Alkmaar
}

